\title{
Large-panel buildings of the series 1-335: economics, ecology, and social aspect
}

\author{
Alexander Petrov ${ }^{1}$, Maria Matveeva ${ }^{1}$, and Alexander Petunin ${ }^{1, *}$ \\ ${ }^{1}$ Irkutsk National Research Technical University, 664074, Lermontova str., 83, Irkutsk, Russia
}

\begin{abstract}
To solve the housing problem is one the most important task of the social and economic development of the regions and of Russia as a whole. One of the aspects of the problem is the large amount of old and dilapidated housing that has accumulated over the previous years. The paper contains data on the state of the housing stock of the Irkutsk region for 2000-2016. The structure of the housing stock has been analyzed. By the present time, the normatively established service life and technical resource of the wall load-bearing and enclosing structures of large-panel buildings of the series 1-335 of the construction of 1960s - 1970s have been exhausted. Specialists came to the common conclusion on this issue.
\end{abstract}

\section{Introduction}

To solve the housing problem is the most important task of the social and economic development of the regions and of Russia as a whole. A lot of scientific research and academic publications are devoted to the analysis of this problem and to the search for approaches, mechanisms, and appropriate tools aimed at improving the situation with providing the population with comfortable and affordable housing. It can be stated that there is certain progress in this direction.

\section{Materials and methods}

One of the aspects of the problem is the large amount of old and dilapidated housing that has accumulated over the previous years. Table 1 presents data on the state of the housing stock of the Irkutsk region for 2000-2016.

Analyzing the structure of the housing stock (Table 2), we would note that most of it is private property. Housing was privatized on the privatization program. The main part of the population is not able to repair it independently.

The panel buildings of the series 335 built in the 1960s is one of the problems of the city of Irkutsk and the Irkutsk region.

*Corresponding author: termina@mail.ru 
Table 1. Housing conditions of the population. Housing stock. (By the end of the year, thousand square meters of total area).

\begin{tabular}{|l|r|r|r|r|r|}
\hline & \multicolumn{1}{|c|}{2000} & 2005 & 2010 & 2015 & 2016 \\
\hline Housing stock as a whole & 49406.3 & 49742.6 & 51870.5 & 55717.1 & 58185.2 \\
\hline $\begin{array}{l}\text { Including dilapidated and } \\
\text { emergency housing [13] }\end{array}$ & 1520.1 & 3290.7 & 4439.6 & 3228.3 & 3061.0 \\
\hline In \% to the total fund & 3.1 & 6.6 & 8.6 & 5.8 & 5.3 \\
\hline $\begin{array}{l}\mathrm{M}^{2} \text { of total area average to one } \\
\text { inhabitant }\end{array}$ & 18.8 & 20.0 & 21.4 & 23.1 & 24.2 \\
\hline $\begin{array}{l}\text { Total area of capitally } \\
\text { renovated housing }\end{array}$ & 79.7 & 736.1 & 804.3 & 320.4 & $\ldots$ \\
\hline
\end{tabular}

Analyzing the structure of the housing stock (Table 2), we would note that most of it is private property. Housing was privatized on the privatization program. The main part of the population is not able to repair it independently.

The panel buildings of the series 335 built in the 1960s is one of the problems of the city of Irkutsk and the Irkutsk region.

Table 2. The structure of the housing stock by forms of ownership (in percent).

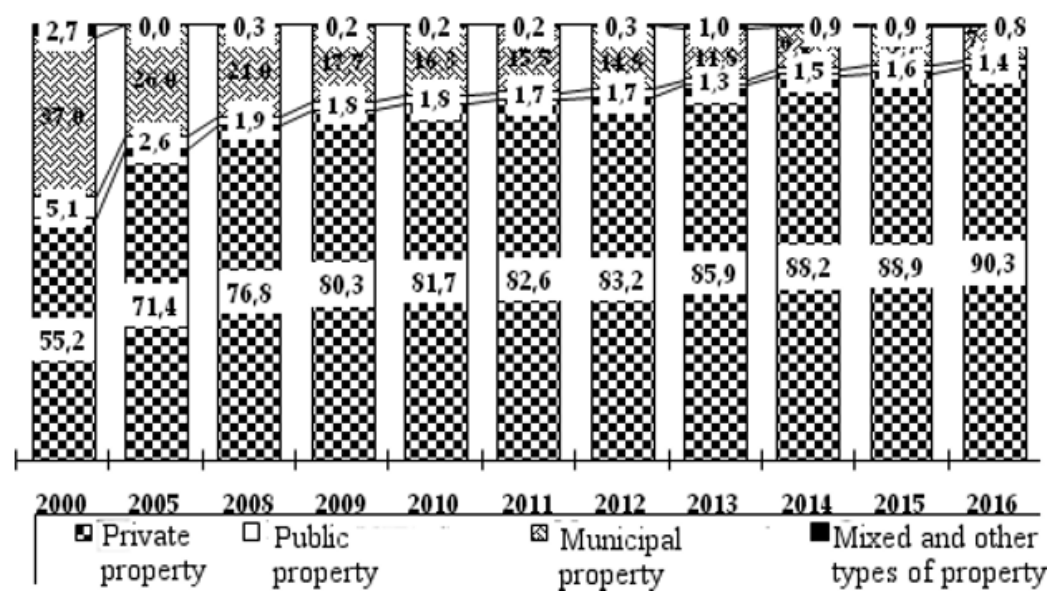

In the past 15-20 years, the need for modernization and reconstruction of large-panel buildings of the series 1-335 of various modifications in the Irkutsk region has grown sharply. The minimum necessary volume of reconstruction of these buildings in Irkutsk is more than 700,000 square meters of the total area. For comparison, in 2017, 966,084 square meters of living space was built in the Irkutsk region.

\section{Results}

By the present time, the normatively established service life and technical resource of the wall load-bearing and enclosing structures of large-panel buildings of the series 1-335 of the construction of 1960s and 1970s have been exhausted. Numerous surveys and regional certification data confirm the presence of defects, damages and destruction of materials, separately and in combination, indicating a decrease in the operational reliability of buildings 
of this type. For seismically active areas, regulatory requirements have significantly increased, to which the buildings in question cannot objectively correspond completely. In addition, wall panels made of gas ash concrete do not meet the requirements of the current norms for energy-saving conditions more than 3 times.
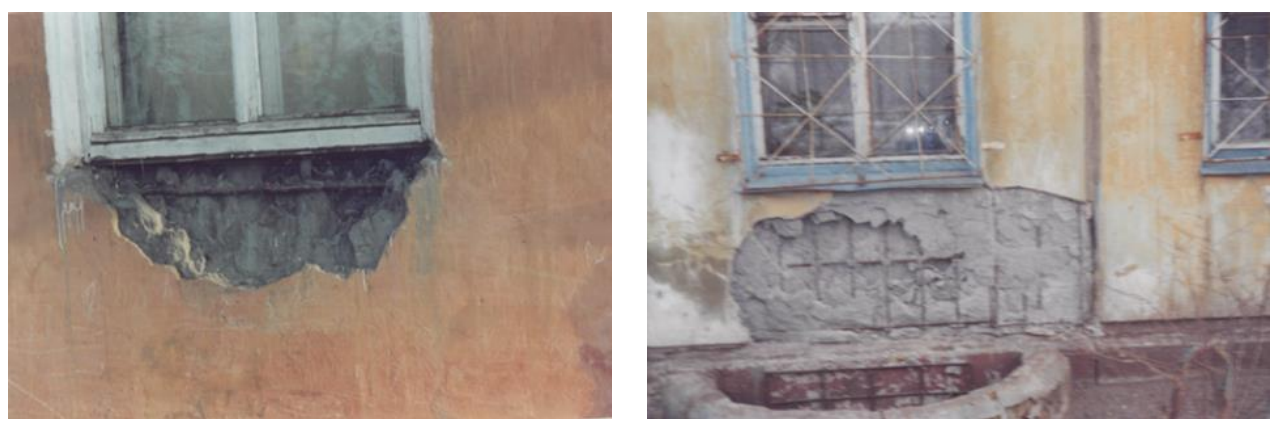

Fig. 1. Destruction gas ash concrete in window areas.
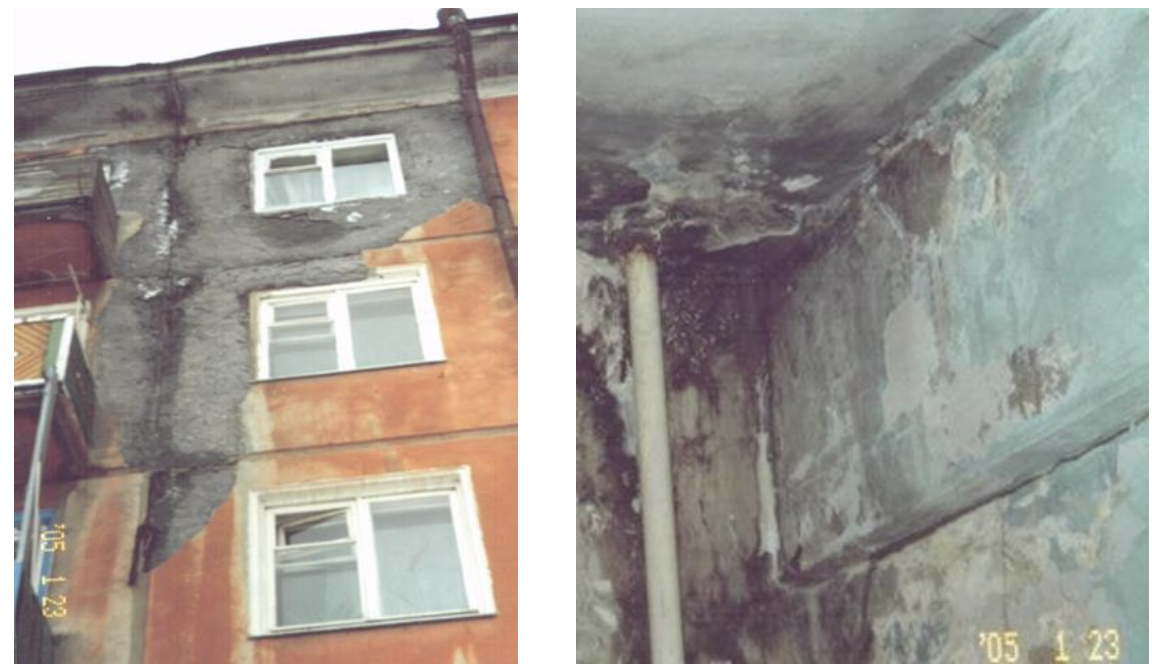

Fig. 2. Exfoliation of a part of the external surface of the NS-type panels from gas-ash concrete with deformation of the bolt.

In the last 5-10 years, many experts agree that the buildings of these series are to be demolished, and new modern residential buildings that meet the criteria for safety of life, energy efficiency and comfort of living are to be built in their place. Practical steps in this direction are not yet taken. In addition, demolition involves the resettlement of residents, and for this, a temporary housing fund should be formed, which is not available in the region. It is difficult to determine the sources of financing for the dismantling and disposal of old houses, and the construction of new housing. To bring this housing stock in accordance with the requirements of comfortable living, it is necessary to determine the forms and mechanisms of professional interaction, taking into account the economic interests of all participants of this process.

\section{Discussion}

Thus, the problem of practical implementation of the demolition of residential buildings affects many aspects, such as economic, technical, environmental, social, and others ones. 
At present, a federal program for the resettlement of citizens from the emergency housing in 2013-2017 is effective in Russia. If the house is recognized as an emergency, then there are two options for solving this problem. The first option involves a major overhaul. The second option is implemented if the overhaul cannot be carried out. In such a situation, citizens are subject to resettlement to new residential complexes.

The main rule of resettlement is the observance of the equivalence of housing. In other words, the area of a new apartment is to be equivalent to the area of the current residence (but not less than $18 \mathrm{~m}^{2}$ per person). In addition, the living conditions and the level of improvement should be no worse than at the previous place without taking into account its accident rate.

According to the Set of Rules 54.13330.2011: "Residential apartment buildings", in new apartments area should be at least: the total square of living room in a one-room apartment $14 \mathrm{~m}^{2}$, in the apartments with the number of rooms two or more $-16 \mathrm{~m}^{2}$, bedrooms $-8 \mathrm{~m}^{2}$ ( $10 \mathrm{~m}^{2}$ for two people); the square of kitchen $-8 \mathrm{~m}^{2}$. Kitchens in the buildings of the series 1-335 have an area of $5.8 \mathrm{~m}^{2}$, and the living area of two-room apartments is $25.4 \mathrm{~m}^{2}$, which is much lower than the normatively required indicators. Therefore, when designing spaceplanning solutions for new buildings, adhering to the rule of equivalence of housing with the observance of town-planning standards is very difficult, and sometimes impossible.

\section{Conclusions}

For today, the issue remains disputable, despite the fact that similar issues in Moscow are resolved in the framework of renovation of old residential buildings (Khrushchevka). In our region, the final decision depends on a number of aspects. The main one, of course, is financing. In this part, a program should be developed with funding from various sources, such as the federal budget, the entity budget, the budget of the Irkutsk region, the Irkutsk city budget, and private investments.

\section{References}

1. A. V. Petrov, V. V. Peshkov, A. G. Petunin, Proceedings of the Irkutsk State Technical University, 11(106), 85-91 (2015)

2. A. V. Petrov, A. G. Petunin, Izvestiya Vuzov. Investments. Building. Real Estate, 2(3), 105-110 (2012)

3. V. K. Averyanov, S. N. Bulgakov, S. A. Chistovich, Industrial and Civil Engineering, 2, 51-55 (1997)

4. A. A. Afanasyev, E. P. Matveev, V. P. Monastyrev, Industrial and Civil Engineering, 6, 49-52 (1997)

5. M. D. Boyko, Maintenance and repair of buildings and structures (Stroyizdat, Moscow, 1993)

6. P. A. Konovalov, Foundations and foundations of reconstructed buildings (Stroyizdat, Moscow, 1980)

7. V. R. Mikhalko, Repair of structures of large-panel buildings (Stroyizdat, Moscow, 1986)

8. Problems of complex reconstruction of residential buildings of series 1.335. Sat. sci. tr. and materials of the inter-regional meeting (SibADI Publishing House, Omsk, 1994)

9. M. D. Spector, Selection of the optimal options for the organization and technology of construction (Stroyizdat, Moscow, 1980) 
10. M. Y. Veselovsky, M. A. Izmailova, A. V. Bogoviz, S. V. Lobova, Y. V. Ragulina, Quality - Access to Success, 19(163), 30-36 (2018)

11. D. V. Dayneko, A. I. Dayneko, V. V. Peshkov, N. Ya. Kalyuzhnova, Proceedings of High Schools. Investments. Building. Real Estate, 7, 3(22), 116-120 (2017)

12. V. V. Peshkov, P. I. Kasyanchik, Economic Journal, 1(1-2), 50 (2014)

13. Starting with the 2015 report, data on the emergency housing stock, according to the changes made to the Federal plan of statistical works approved by the Order of the Government of the Russian Federation No. 994-p of 25.05.2016 are provided to the users of official statistical information by the Ministry of Construction of the Russian Federation 